\title{
Adsorptive Removal Study of the Frequently Used Fluoroquinolone Antibiotics - Moxifloxacin and Norfloxacin from Wastewaters using Natural Zeolites
}

\author{
Imeda Rubashvili *, Luba Eprikashvili, Teimuraz Kordzakhia, Marine Zautashvili, Nino Pirtskhalava \\ and Maia Dzagania
}

Petre Melikishvili Institute of Physical and Organic Chemistry at Ivane Javakhishvili Tbilisi State University, Tbilisi, Georgia

\begin{abstract}
Residual antibiotics pollution has become one of the most severe environmental problems today. Antibiotics from hospitals and drug factories represent a potential risk for human and ecological health. Therefore, it has been a high exigency to develop some efficient and cost-effective treatment methods and technologies for antibiotics removal from industrial and household contaminated water. Adsorption is one of the most utilised techniques and has many competitive advantages such as the unique properties of flexibility, effectiveness, superior performance and the robustness for consecutive cycles. The present research concerns the adsorption of two frequently used fluoroquinolone antibiotics - moxifloxacin and norfloxacin on natural zeolite - clinoptilolite and its acid-modified form from aqueous solutions. For the first time, the adsorption of the antibiotics mentioned above on the selected natural zeolite was investigated under static and dynamic conditions. Adsorption experiment under dynamic conditions carried out using the specially constructed dynamic type of laboratory equipment. The effect of the inlet concentration, the flow rate and the $\mathrm{pH}$ value of the antibiotic solution, also, the contact time of system zeolite/antibiotic solution on the adsorption process were examined and evaluated using the Langmuir and Freundlich adsorption models. The results showed that the highest static adsorption capacities were observed at low initial concentration $-0.2 \mathrm{mg} / \mathrm{mL}$ of antibiotic solution for both adsorbents; the highest dynamic adsorption capacities - at low flow rate $-1.5 \mathrm{mg} / \mathrm{mL}$ and low inlet concentration $-0.2 \mathrm{mg} / \mathrm{mL}$ of antibiotic solution for both adsorbents. The static adsorption capacity was up to $2.71 \mathrm{mg} / \mathrm{g}$ for moxifloxacin hydrochloride; $4.14 \mathrm{mg} / \mathrm{g}$ for norfloxacin and the dynamic adsorption capacity was up to $1.20 \mathrm{mg} / \mathrm{g}$ for moxifloxacin hydrochloride; $2.10 \mathrm{mg} / \mathrm{g}$ for norfloxacin at a neutral $\mathrm{pH}$ value and constant temperature of $200^{\circ} \mathrm{C}$. Each antibiotic was determined quantitatively in sample solutions using the developed and validated HPLC methods with a limit of quantitation $0.05 \mu \mathrm{g} / \mathrm{mL}$. Hence, this study demonstrates and proves that natural zeolite could be an effective adsorbent for the removal of the selected antibiotics from wastewaters.
\end{abstract}

Keywords: Wastewater; adsorption; norfloxacin; moxifloxacin.

\section{Introduction}

Environmental problems including water, air and soil pollution and climate changes, have attracted more global attention in the $21^{\text {st }}$ century. After penicillin was discovered accidentally by Fleming (1944), the study of antibiotics developed rapidly. Antibiotics are an essential and large group of pharmaceuticals used by humans and animals in order to prevent or treat bacterial infection ${ }^{1,2}$. Global antibiotic consumption has increased by twice over the last decade and internationally, the use of antibiotics has been estimated at 100000 to 200000 tons per year ${ }^{3}$. Due to the extensive use of antibiotics, the occurrence of residual antibiotics in the environment is increasing day by day, which is a potential environmental issue.

*Corresponding author: Imeda rubashvili

Email address: rubashvili@yahoo.fr

DOI: http://dx.doi.org/10.13171/mjc92190921700ar
Antibiotics can be discharged into the environment in several different ways (Figure 1) ${ }^{4,5}$. About 30-90\% of the given antibiotic dose can remain undegradable in the human or animal body which largely excreted as an active compound ${ }^{6}$. The excretion of poorly metabolized antibiotics by humans and animals is the primary source of antibiotic residues in the environment. Other sources are the disposal of unused or unwanted antibiotics from pharmaceutical manufacturing processes ${ }^{7,8}$. Several studies have reported that antibiotics are detected in hospital wastewater, wastewater treatment plant (WWPT) influents and effluents, surface waters, groundwater, sediment, and drinking water ${ }^{3,4,9}$. In aquatic systems, the detected antibiotic concentrations were high at $\mu \mathrm{g} / \mathrm{L}$ level in hospital effluent, wastewaters and low 
over a wide range from $\mathrm{ng} / \mathrm{L}$ to $\mu \mathrm{g} / \mathrm{L}$ in various surface and ground waters. In sediments, the number of antibiotics was low to medium at $\mu \mathrm{g} / \mathrm{kg}$ level ${ }^{10}$. Antibiotics in hospital effluent and WWTP influent are relatively high compared with other locations. Recently, due to their high toxicity to algae and bacteria at low concentrations and their potential to cause resistance amongst the natural bacterial population, antibiotics have been categorized as a priority risk group ${ }^{9}$. Antibiotics in surface water can potentially disrupt bacteria cycles and processes critical to agriculture (soil fertility) and animal production (rudimentary processes) or aquatic ecology (nitrification and denitrification) ${ }^{11}$.

Quinolone antibiotics are synthetic antibacterial drugs with a 4-quinolone basic structure which inhibit bacterial DNA gyrase and cause cells to stop dividing, resulting in irreversible damage to bacteria. The most commonly used quinolones comprise a new series of antibiotics called fluoroquinolone (FQ) antibiotics ${ }^{12}$. The presence of fluorine atoms is a critical factor for high activity; the activity of this antibiotic increased by approximately tenfold. Fluoroquinolones can inhibit the proliferation of many Gram-negative and Gram-positive bacteria ${ }^{13}$, so, they have been widely used in human medicine. However, as a result of antibiotic overuse, public concern about FQs has significantly been increasing in the past decades. The environmental concern of FQ antibiotics residues in the aquatic environments is not only on their potential to increase antibiotic resistance but also on their unfavourable ecotoxicity profile ${ }^{14}$.

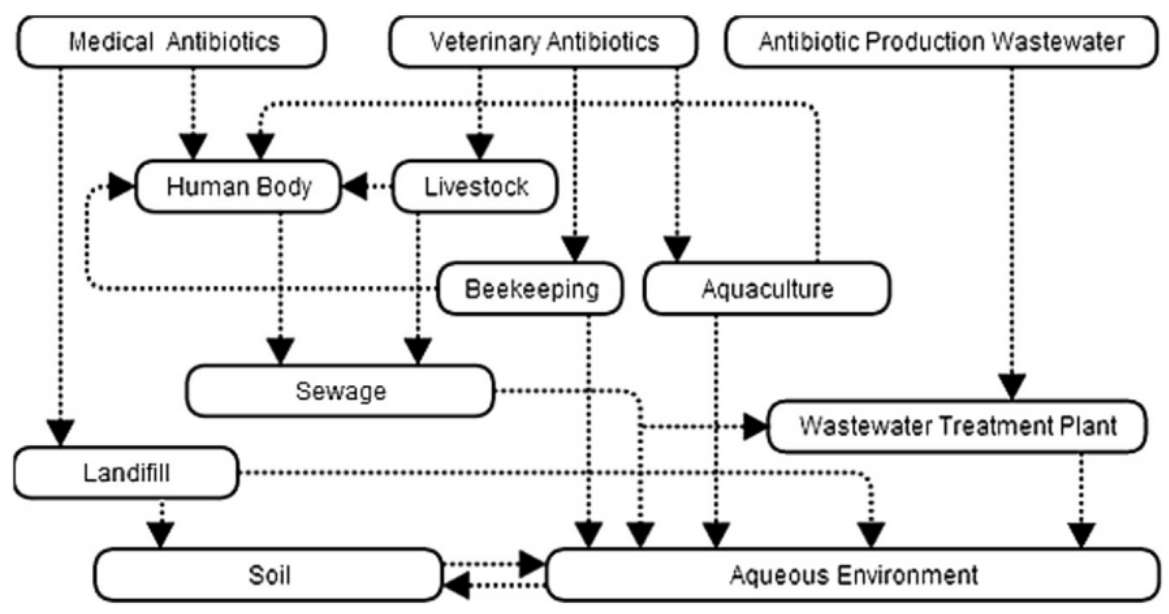

Figure 1. The presence of antibiotics in the environment

Table 1. The structure and main physicochemical properties of FQs and their content in surface water.

\begin{tabular}{|c|c|c|}
\hline Compound & Moxifloxacin & Norfloxacin \\
\hline Molecular formula & $\mathrm{C}_{21} \mathrm{H}_{24} \mathrm{FN}_{3} \mathrm{O}_{4}$ & $\mathrm{C}_{16} \mathrm{H}_{18} \mathrm{FN}_{3} \mathrm{O}_{3}$ \\
\hline CAS number & $354812-41-2$ & $70458-96-7$ \\
\hline Abbreviation & MOX & NOR \\
\hline Molecular structure & & \\
\hline Molecular weight, g/mol & 401.438 & 319.331 \\
\hline $\begin{array}{l}\text { The acid dissociation } \\
\text { constants, pKa }\end{array}$ & $\mathrm{pKa} 1=6.43 ; \mathrm{pKa} 2=10.63$ & $\mathrm{pKa} 1=0.16 ; \mathrm{pKa} 2=8.68$ \\
\hline Chemical name & $\begin{array}{c}\text { (4aS-cis)-1-Cyclopropyl-6-fluoro- } \\
\text { 1,4-dihydro-8-methoxy-7- } \\
\text { (octahydro-6H-pyrrolol[3,4- } \\
\text { b]pyridin-6-yl)-4-oxo-3- } \\
\text { quinolinecarboxylic acid }\end{array}$ & $\begin{array}{c}\text { 1,4-Dihydro-1-ethyl-6-fluoro-4-oxo-7- } \\
\text { (1-piperazinyl)-3-quinolinecarboxylic } \\
\text { acid }\end{array}$ \\
\hline $\begin{array}{l}\text { Water solubility, } \\
\mathrm{mg} / \mathrm{mL} \text { at } 25^{\circ} \mathrm{C} \text { and pH 5-7.5 }\end{array}$ & $1.15-5$ & $0.45-161$ \\
\hline $\begin{array}{l}\text { Concentration in surface } \\
\text { water, } \mu \mathrm{g} / \mathrm{L}\end{array}$ & $0.006-0.017$ & $0.0023-0.12$ \\
\hline $\begin{array}{l}\text { Toxicity, oral LD50 (rat), } \\
\text { g/kg }\end{array}$ & 1.32 & 4 \\
\hline
\end{tabular}


Moxifloxacin and norfloxacin belong to the fluoroquinolone antibiotics family. These active pharmaceutical ingredients are frequently used in medical and veterinary practice. The presence of FQs residues in effluents from households, hospitals, and pharmaceutical industries is a significant cause of acute and chronic toxicity, as well as the emergence of resistant bacteria. Consequently, removal of FQ residues from the environment is a crucial issue ${ }^{15,16}$. The structure and main physicochemical properties, as well as the concentrations of moxifloxacin and norfloxacin in different environmental compartments 5, 17-22 are listed in Table 1.

Various methods to treat residual antibiotics have been developed, including ozonation, chlorination, ultraviolet (UV) irradiation, nano-filtration (NF), reverse osmosis (RO) filtration, and adsorption by activated carbons and other materials ${ }^{23}$. It has been reported that conventional biological processes (wastewater treatment plants) are incapable of removing antibiotic pollutants ${ }^{24}$. Many techniques have been used for the treatment of FQs-rich effluents such as electrochemical oxidation ${ }^{25}$, biodegradation ${ }^{26}$, photodegradation ${ }^{27}$, catalytic degradation ${ }^{28}$, micro-extraction ${ }^{29}$, oxidation (catalytic degradation) ${ }^{30}$, and adsorption ${ }^{31}$.

Adsorption is one of the most widely used techniques for removal of a broad range of various pollutants due to its simple design, smooth operation, low cost, no by-product formation and relatively simple regeneration. Adsorption is considered as an effective method to remove FQ antibiotics from various contaminated media, and there is a need for inexpensive, effective adsorbents for the removal of the antibiotics mentioned above at low concentration from wastewater. Recently, many studies focused on adsorption of pollutants, including antibiotics by porous materials, such as zeolites and activated carbons 5,18,27,35-44. However, adsorption of FQ antibiotics, namely moxifloxacin and norfloxacin on natural zeolite as a cost-effective adsorbent has not been addressed yet by researchers.

The present work is the first case where the adsorptive removal of the two most commonly used fluoroquinolones - moxifloxacin and norfloxacin from aqueous solutions by natural zeolite clinoptilolite (CL) has been investigated under static and dynamic conditions. It has been demonstrated that the selected natural zeolite - clinoptilolite from the local region, Georgia and its acid-modified $\mathrm{H}$-form (H-CL) obtained with simple acidic treatments, is a potential adsorbent and has an economically feasible means of FQ antibiotics removal from wastewaters.
Natural zeolites as hydrated aluminosilicates characterized by high surface area and high cation exchange capacities (CECs), can be potentially used to remove some antibiotics with positively charged moieties through cation exchange. Like clays, zeolites are negatively surface charged, and internal and external surface areas up to $800 \mathrm{~m}^{2} / \mathrm{g}$. Total CECs in natural zeolites vary from 250 to $3000 \mathrm{mEq} / \mathrm{kg}$, and external cation exchange capacities (ECECs) typically range from 10 to $50 \%$ of the total cation exchange capacity. Zeolites have rigid threedimensional crystalline structures free of the shrinkswell behaviour typical of smectite clays. Zeolites and clay minerals have a similar composition. However, they have different crystalline structures. Natural zeolite has a frame, open and stable structure with symmetrically stacked alumina and silica tetrahedrons 45,46 . Natural clinoptilolite belongs to the group of heulandite zeolites and is one of the most widespread zeolites in nature. The crystal structure of clinoptilolite is characterized by quite open channels formed with ten- and eight-membered tetrahedral rings arranged in three directions: the channels parallel to the $\mathrm{C}$ axis have the following dimensions: $0.705 \times 0.425 \mathrm{~nm}$ and $0.460 \times 0.395 \mathrm{~nm}$, respectively. Eight-membered channels, arranged in parallel and at 500 angle to the $\mathrm{A}$-axis, have diameters of $0.540 \times 0.390$ and $0.520 \times 0.390 \mathrm{~nm}^{47,48}$.

\section{Experimental}

\subsection{Preparation of adsorbent}

The local natural zeolite with the zeolitic phase content - 55-65\% - clinoptilolite was obtained from Khandaki Kartli region, Georgia. Clinoptilolite was ground by ball mills at ambient temperature. The vessel was rotated with the speed of $1500 \mathrm{rpm}$. After milling the adsorbent in powdered form was washed with deionized water for twice and dried under nitrogen flow at $300^{\circ} \mathrm{C}$ for 3 hours. For obtaining a modified $\mathrm{H}$-form of natural clinoptilolite was treated with an acidic solution (2M $\mathrm{HCl}$ solution) at $400^{\circ} \mathrm{C}$ for 2 hours. The removal efficiency of oxide elements by $2 \mathrm{M} \mathrm{HCl}$ solution is higher than other acid solutions 47-49. In hydrothermally treated adsorbent samples with $\mathrm{HCl}$ solution, $\mathrm{Si} / \mathrm{Al}$ ratio was increased ( $\mathrm{Si} / \mathrm{Al}$ ratio $>4$ and $\mathrm{Na}+\mathrm{K} / \mathrm{Ca}+\mathrm{Mg}$ ratio $<1)$. The scheme of the acid treatment and the structure of clinoptilolite are shown in Figure 2. The obtained powdered adsorbent was separated into a fraction with particle sizes of $0.5-1.0 \mathrm{~mm}$. Chemical composition of the natural clinoptilolite adsorbent was determined by chemical quantitative analysis and the obtained results are $\mathrm{SiO}_{2}-66.51 \%, \mathrm{Al}_{2} \mathrm{O}_{3}-12.41 \%, \mathrm{Fe}_{2} \mathrm{O}_{3}-1.97 \%$, $\mathrm{Na}_{2} \mathrm{O}-2.65 \%, \mathrm{~K}_{2} \mathrm{O}-1.52 \%, \mathrm{CaO}-1.95 \%, \mathrm{MgO}-$ $1.14 \%$. The canal sizes are $0.39 \times 0.54 \mathrm{~nm}$. 


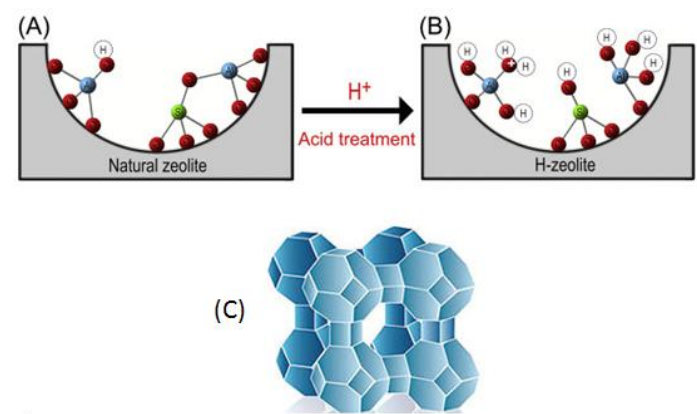

Figure 2. The scheme of the acid treatment ( $\mathrm{A}$ - natural zeolite; $\mathrm{B}-\mathrm{H}$-zeolite) and the structure of clinoptilolite (C)

\subsection{Reagents, chemicals, and instrumentation}

The certified analytical standards of moxifloxacin hydrochloride and norfloxacin, the HPLC grade acetonitrile and the analytical grade were purchased from Merk.

The specially constructed laboratory dynamic type equipment with fixed bed adsorption glass column packed by zeolite adsorbent and chromatography pump was used in the adsorption experiment which was carried out at a constant temperature of $20^{\circ} \mathrm{C}$ in the laboratory room with temperature-controlled conditions. Figure 3 shows a schematic illustration of the apparatus used for the investigation of adsorption under dynamic conditions. The upper and lower parts of the column contained plastic pellets to compact the bed and avoid a dead volume and channelling. The concentration of adsorbate in the influent and effluent stream was determined using the previously developed and validated effective and sensitive HPLC methods. The limit of quantitation of both analytical methods for the quantitative determination of norfloxacin and moxifloxacin $\mathrm{HCl}$ is $0.05 \mu \mathrm{g} / \mathrm{mL}^{50}$.

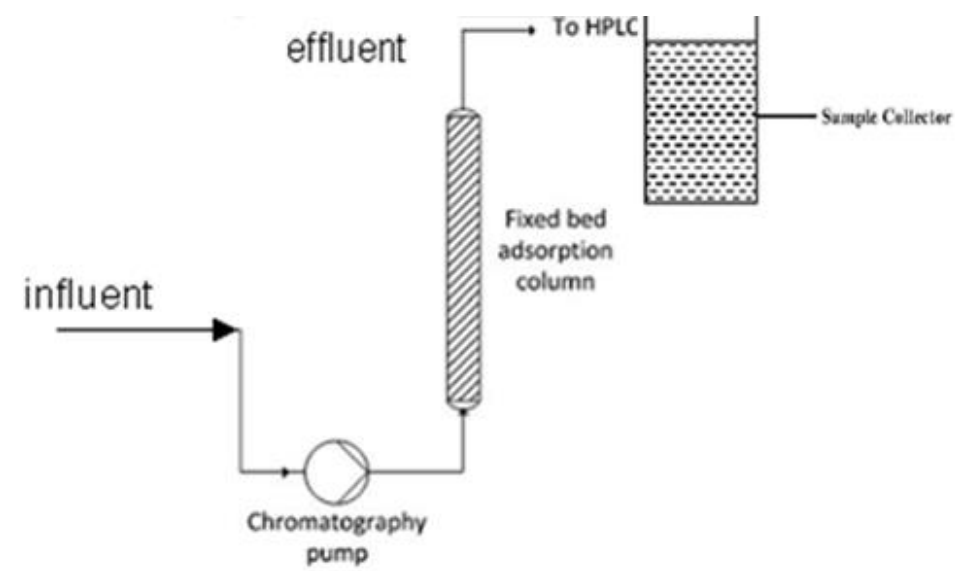

Figure 3. The laboratory dynamic type equipment for adsorption study

The chromatographic analysis was performed using LC-20AD Prominence Shimadzu HPLC System (Japan) and HPLC column - Agilent SB-C18 $4.6 \mathrm{x}$ $250 \mathrm{~mm}, 5 \mu \mathrm{m}$ (USA). The HPLC grade water was prepared using Milli Q Advantage A10 purification system (France). Analytical balance ALX-210 (USA) and Hanna Instruments HI 2211 pH-meter (USA) were used for standard and sample preparation. X-ray diffraction (XRD) analysis was performed by a Bruker D5000 X-ray powder diffraction (XRD) system (Germany). All the measuring equipment were appropriately calibrated and qualified.

Moxifloxacin $\mathrm{HCl}$ and norfloxacin solutions at $0.1 \mathrm{mg} / \mathrm{mL}$ concentration (prepared by two-step dilution; diluent - mobile phase of HPLC method for step 1; diluent - purified water for step 2) were used as standard solutions for HPLC analysis. Moxifloxacin $\mathrm{HCl}$ and norfloxacin analytical standards diluted in purified water were used as adsorbate - sample (influent) solutions with different concentrations - from $0.2 \mathrm{mg} / \mathrm{mL}$ to $2.0 \mathrm{mg} / \mathrm{mL}$. The initial $\mathrm{pH}$ value of the sample solution was adjusted by adding $0.1 \mathrm{M} \mathrm{NaOH}$ and $\mathrm{HCl}$ solution.

\subsection{Adsorption experiment}

The following procedure was employed in order to study adsorption under static conditions. $0.2 \mathrm{~g}$ of adsorbent was transferred to a $250 \mathrm{~mL}$ flask and added $20 \mathrm{~mL}$ of the prepared FQ antibiotic solution at $0.2-2.0 \mathrm{mg} / \mathrm{mL}$ concentration range. Initially, the adsorbent sample was left on an orbital shaker at 150 rpm for $15 \mathrm{~min}$ and then for $170 \mathrm{hrs}$. At the end of the experiment, the adsorbent sample was centrifuged at $3000 \mathrm{rpm}$ for $5 \mathrm{~min}$. The obtained supernatant was used to determine the concentration of each FQ antibiotic. The sample solutions were taken at different time intervals during the experiment, as well. Their concentrations were determined using the HPLC method. 
In order to examine adsorption under dynamic conditions, the laboratory equipment with fixed bed adsorption glass column (internal diameter $-1.0 \mathrm{~cm}$ and length $-8 \mathrm{~cm}$ ) packed with $9 \mathrm{~g}$ of zeolite adsorbent was used. The moxifloxacin $\mathrm{HCl}$ and norfloxacin solutions with different concentrations were added to a glass beaker and pumped into the column with various flow rates. The flow rate of the influent stream was varied from 1.5 to $5.0 \mathrm{~mL} / \mathrm{min}$. The effluent samples were collected at different time intervals until the saturation state occurred. The effect of working parameters such as the value of $\mathrm{pH}$, the flow rate and the initial concentration of FQ solution were investigated. One additional glass flask was left under the same conditions, in order to evaluate possible degradation of FQ antibiotics with aliquots being removed analysis at every time interval and no significant losses were observed.

The breakthrough curves for adsorption of each FQ antibiotic - moxifloxacin $\mathrm{HCl}$ and norfloxacin on the selected zeolite adsorbents - CL and $\mathrm{H}-\mathrm{CL}$ in terms of the effluent to influent concentrations ratio, $\mathrm{C} / \mathrm{C}_{0}$, versus the contact time $-\tau$, min were investigated by carrying out a set of fixed bed experiments at constant temperature of $20^{\circ} \mathrm{C}$.

\subsection{Calculations}

The concentration of each drug compound $-\mathrm{C}_{\mathrm{u}}$ in an effluent sample solution, expressed in $\mathrm{mg} / \mathrm{mL}$ was calculated by the following equation:

\section{$C_{u}=A_{u} \times W \times D_{1} \times P / A_{s} \times D_{2} \times 100$}

where, $A_{u}$ - The peak area of each FQ antibiotic obtained with the influent/effluent sample solution; $A_{s}$ - The peak area of each FQ antibiotic obtained with the standard solution; W - The weight of FQ standard, $\mathrm{mg} ; \mathrm{D}_{1}$ - The dilution factor of the sample solution; $\mathrm{D}_{2}$ - The dilution factor of the standard solution; $\mathrm{P}$ The purity of analytical standard, $\%$.

The removal efficiency - R, \% was calculated by the following equation:

\section{$\mathrm{R}, \%=\left(\mathrm{C}_{0}-\mathrm{C}_{\mathrm{e}}\right) \times 100 / \mathrm{C}_{0}$}

where, $C_{e}$ - The equilibrium concentration of adsorbate in the adsorbate solution at the fixed time (contact time with adsorbent $-\tau, \mathrm{hrs}$ ), $\mathrm{mg} / \mathrm{mL} ; \mathrm{C}_{0}$ The initial concentration in the adsorbate solution, $\mathrm{mg} / \mathrm{mL}$.

The static adsorption capacity - $\mathrm{q}_{\mathrm{s}}, \mathrm{mg} / \mathrm{g}$ was calculated by the following equation:

$\mathrm{q}_{\mathrm{s}}=\left(\mathrm{C}_{0}-\mathrm{C}_{\mathrm{e}}\right) \times \mathrm{V} / \mathrm{m}$

where, V - The used volume of the adsorbate solution, $\mathrm{mL} ; \mathrm{m}$ - The mass of adsorbent, $\mathrm{g}$.

The dynamic adsorption capacity $-\mathrm{q}_{\mathrm{d}}, \mathrm{mg} / \mathrm{g}$ was calculated by the following equation:

\section{$q=q_{e} \times\left(1-L_{0} / L\right)$}

where, $\mathrm{q}_{\mathrm{e}}$ - The equilibrium adsorption capacity, $\mathrm{mg} / \mathrm{g} ; \mathrm{L}-$ The bed depth, $\mathrm{cm} ; \mathrm{L}_{0^{-}}$The height of mass transfer zone of the bed, cm, calculated by the following equation:

$\mathrm{L}_{0}=\mathrm{L} \times\left(\mathrm{t}_{\mathrm{s}}-\mathrm{t}_{\mathrm{b}}\right) / \mathrm{t}_{\mathrm{s}}-(1-\phi) \times\left(\mathrm{t}_{\mathrm{s}}-\mathrm{t}_{\mathrm{b}}\right)$

where, $t_{s}=V_{s} / F$, the time necessary for bed saturation, min; $\mathrm{V}_{\mathrm{s}}$ - The volume of solvent flowing up to the instant of bed saturation, $\mathrm{mL}$; $\mathrm{F}$ - The flow rate, $\mathrm{mL} / \mathrm{min} ; \mathrm{t}_{\mathrm{b}}=\mathrm{V}_{\mathrm{b}} / \mathrm{F}$, the time for bed breakthrough, min; $\mathrm{V}_{\mathrm{b}}$ - The volume of antibiotic solution flowing up to the instant of bed saturation, $\mathrm{mL} ; \phi=\mathrm{S}_{\mathrm{A}} /\left(\mathrm{S}_{\mathrm{A}}+\mathrm{S}_{\mathrm{B}}\right)$, the symmetry coefficient of the breakthrough curve; $\mathrm{S}_{\mathrm{A}}-$ The area above the breakthrough curve up to the moment of bed saturation and $\mathrm{S}_{\mathrm{B}}$ - the area under the breakthrough curve up to the moment of bed saturation $^{51}$.

The mechanism of adsorptive removal of FQ antibiotics and the interaction of zeolite adsorbent with FQ antibiotic were described by the adsorption isotherms using Langmuir and Freundlich isotherm models. The Langmuir model assumes monolayer adsorption on the surface of the adsorbent containing a limited number of adsorptive sites with uniform energies. Freundlich isotherm model can be used for the adsorption onto heterogeneous surfaces and multilayer adsorption with different energies ${ }^{38}$. The initial concentrations of FQ antibiotic solutions varied within a range from $0.5 \mathrm{mg} / \mathrm{mL}$ to $2 \mathrm{mg} / \mathrm{mL}$. Based on the adsorption experiment data isotherms were plotted describing the relationship between the uptake of adsorbate and the adsorbate equilibrium concentration remaining in the solution after the system has attained the equilibrium state at a constant temperature of $20^{\circ} \mathrm{C}$. The Langmuir model was demonstrated by the following equilibrium equation:

$1 / q_{e}=1 / q_{m} \times K_{L} \times C_{e}+1 / q_{m}$

and the Freundlich model -

$q_{e}=K_{F} \times C_{e} e^{1 / n}$

where, $\mathrm{q}_{\mathrm{e}}$ - The uptake of the adsorbate (the equilibrium adsorption capacity), mg/g, $\mathrm{q}_{\mathrm{m}}$ - The monolayer adsorption capacity of adsorbent, $\mathrm{mg} / \mathrm{g} ; \mathrm{K}_{\mathrm{L}}$ - The Langmuir adsorption equilibrium constant, $\mathrm{mL} / \mathrm{mg} ; \mathrm{K}_{\mathrm{F}}, \mathrm{mL} / \mathrm{mg}$ and $\mathrm{n}$ - The Freundlich adsorption equilibrium constants. The equation (7) can be linearized by taking logarithms:

$\log q_{e}=\log K_{F}+1 / n \times \log C_{e} 52,53$

\section{Results and Discussions}

In order to obtain the acid-modified $\mathrm{H}$-form of clinoptilolite crystal structural changes of natural clinoptilolite after the acid treatment was investigated using XRD analysis. The XRD patterns of the prepared adsorbent samples of CL and H-CL are given in Figure 4, which shows that intensities of the diffraction peaks are reduced for a sample of $\mathrm{H}-\mathrm{CL}$ in comparison with the sample of CL. This decrease is characterized by the ratio of intensities (I) of characteristic peaks of CL $\left(2 \theta=9.9^{\circ}, 22.4^{\circ}\right.$ and $\left.30.0^{\circ}\right)$ to that for a quartz phase at $2 \theta=26.6^{\circ}\left(\mathrm{I}_{0}\right)$. Reduction 
of the intensity of the sample of $\mathrm{H}-\mathrm{CL}$ is connected with the known removal of cations and aluminium from CL caused by the acidic treatment with $0.1 \mathrm{M}$ $\mathrm{HCl}$ solution. It is also evident that decline in the relative intensity of diffraction peaks $\left(\mathrm{I} / \mathrm{I}_{0}\right)$ in case of
$\mathrm{H}-\mathrm{CL}$, especially, the diffraction peaks at $9.88^{\circ}$ and $22.36^{\circ}$ is associated with an increase in crystallinity compared to CL. This indicates an increase in the relative content of $\mathrm{Si} / \mathrm{Al}$ ratio in the zeolite framework and pore opening compared to CL.

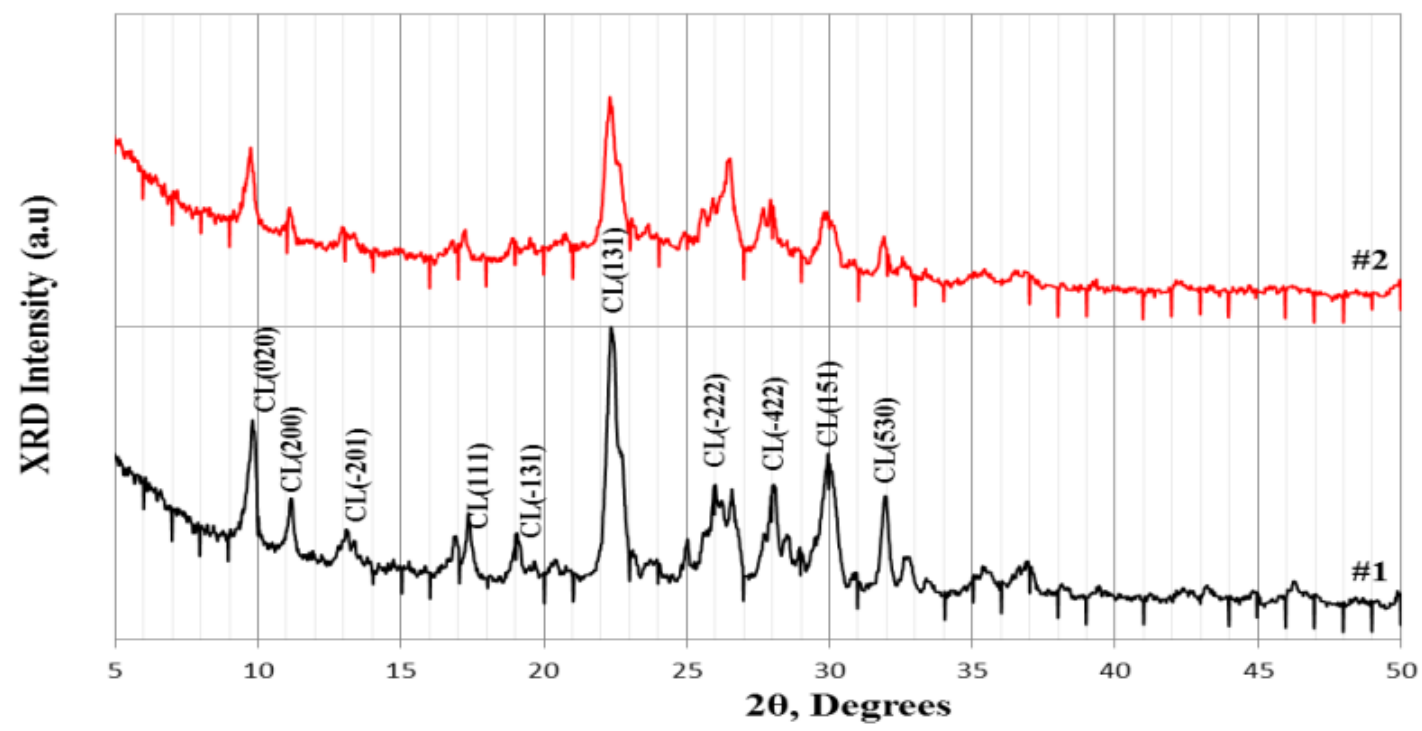

Figure 4. XRD patterns of the selected adsorbents: 1. Natural clinoptilolite; 2. Clinoptilolite H-form

In order to measure adsorption of the selected adsorbates - MOX $\mathrm{HCl}$ and NOR on CL and H-CL under static conditions at the value of $\mathrm{pH} 7$, the removal efficiency - R, \% was calculated. The adsorption experiment was performed using each $\mathrm{FQ}$ antibiotic solution with three different concentration solutions $-0.5 \mathrm{mg} / \mathrm{mL}, 1.0 \mathrm{mg} / \mathrm{mL}, 2.0 \mathrm{mg} / \mathrm{mL}$. Based on the obtained data, the curves were plotted describing the relationship between the amount of adsorbate (the removal efficiency, \%) and the contact time of adsorbate solution with the adsorbent. The

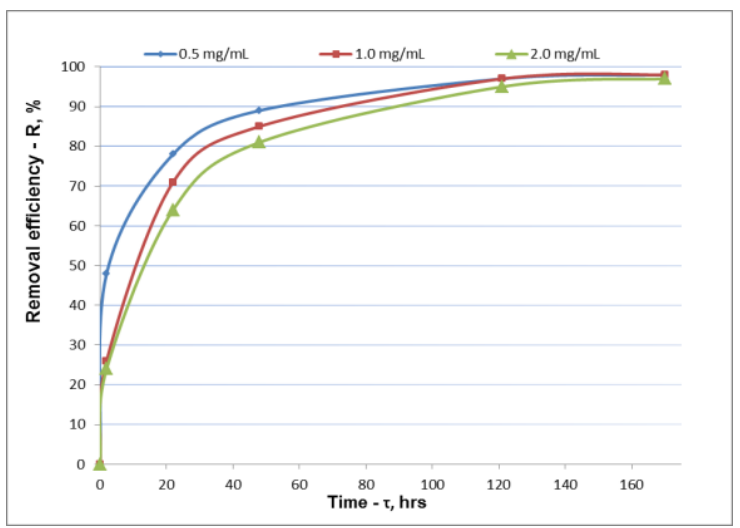

Figure 5. The curve of the removal efficiency, $\%$ versus the concentration of adsorbate solution for NOR/CL system curves for CL and H-CL are given in Figures 5,6, respectively. It will be seen from the curves that the same adsorption process occurred for both adsorbents, but the fastest adsorption was observed in case of NOR different to MOX $\mathrm{HCl}$. The removal efficiency increased with a decrease in the concentration of adsorbate solution. Thus, the amount of FQ antibiotic adsorbed per unit mass of zeolite as a function of the contact time of each adsorbate with adsorbent, the structure, the molecular weight and the concentration of FQ antibiotic in solution.

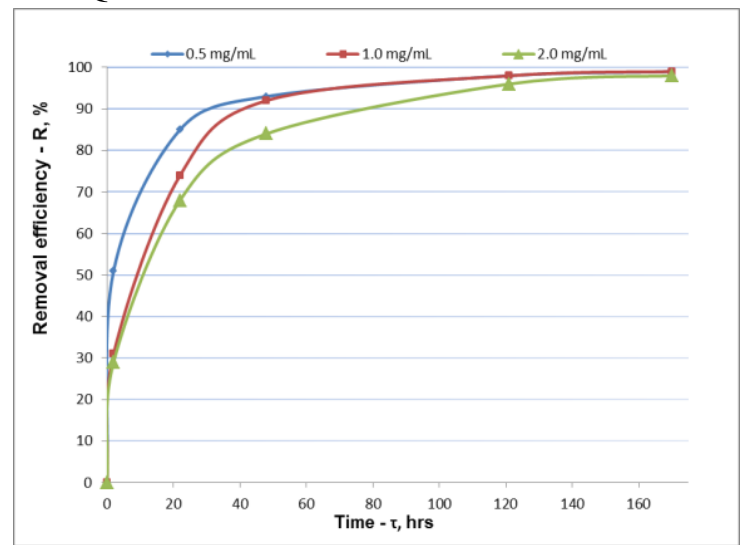

Figure 6. The curve of the removal efficiency, $\%$ versus the concentration of adsorbate solution for MOX HCl/CL system 


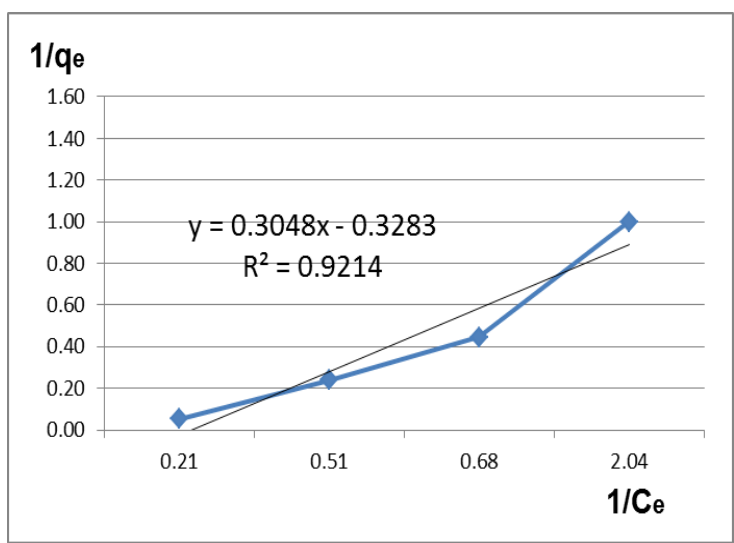

Figure 7. The Langmuir isotherm for NOR adsorption on CL

An adsorption isotherm mainly depends on the equilibrium equation providing valuable information about the adsorbent surface properties and describes the relationship between the equilibrium concentration of the adsorbate and the quantity of adsorbate on the adsorbent surface at a constant temperature. On the base of the results obtained, the adsorption study under static conditions, the adsorption of FQ antibiotics on CL and H-CL were

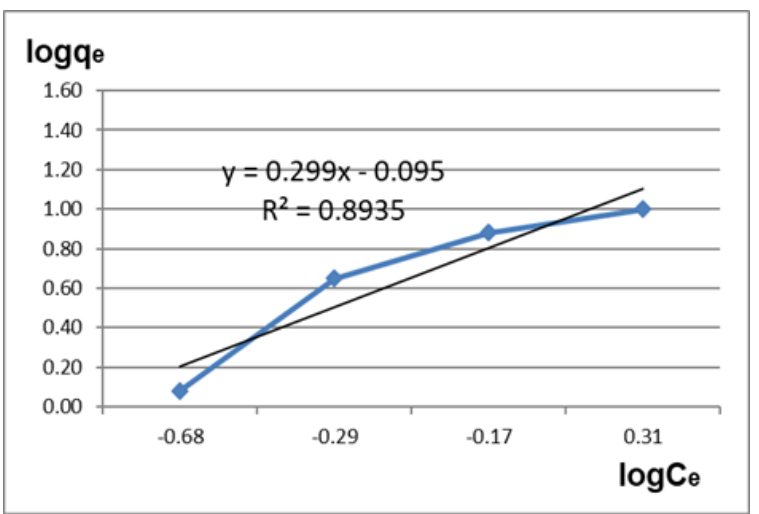

Figure 9. The Freundlich isotherm for $\mathrm{MOX} \mathrm{HCl}$ adsorption on CL

Based on the obtained results, the values of the square of the correlation coefficient for both adsorption isotherms are nearly the same, and they have a reasonable correlation indicating that adsorption process is favourable for natural zeolite as adsorbent. The values of the square of correlation coefficient (R2) for Langmuir isotherms are all above 0.92 $\left(\mathrm{R}^{2}=0.92-0.94\right)$ for both FQ antibiotics. It will be seen that these isotherms have a little bit better correlation compared to Freundlich isotherms $\left(\mathrm{R}^{2}=0.82-0.90\right)$. The data were fitted better by Langmuir isotherm than by Freundlich isotherm. Thus, the Langmuir isotherm model could well interpret the adsorption process. The adsorption of both FQ antibiotics - $\mathrm{MOX} \mathrm{HCl}$ and NOR on the selected adsorbents - clinoptilolite and its acid-treated $\mathrm{H}$-form is driven by the formation of $\mathrm{FQ}$ antibiotic monolayer on the adsorbent surfaces. In this case, the adsorption mechanism mainly composed of

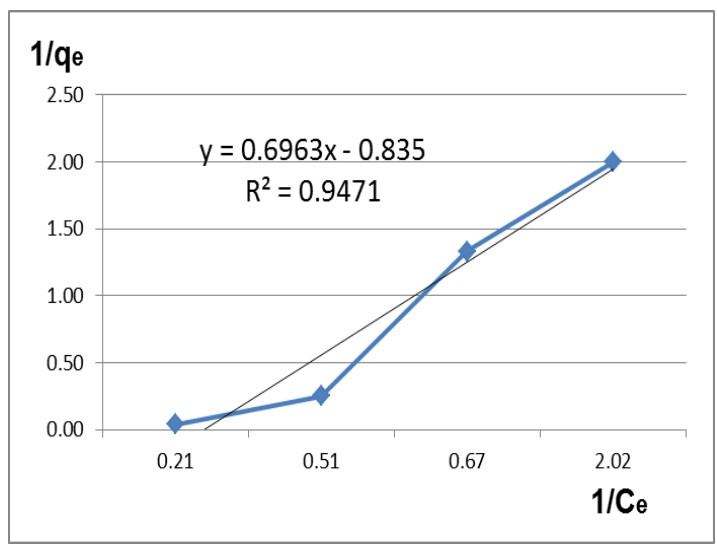

Figure 8. The Langmuir isotherm for $\mathrm{MOX} \mathrm{HCl}$ adsorption on $\mathrm{CL}$

analysed using Langmuir and Freundlich models. The adsorption isotherm experiment carried out using the same mass of zeolitic adsorbent $(0.2 \mathrm{~g})$ and the same volume of adsorbate solution $(20 \mathrm{~mL})$ varying the initial concentration over a range $0.5-2 \mathrm{mg} / \mathrm{mL}$ at a constant temperature of $20^{\circ} \mathrm{C}$. Figures $7,8,9,10$ depicts each adsorption isotherm

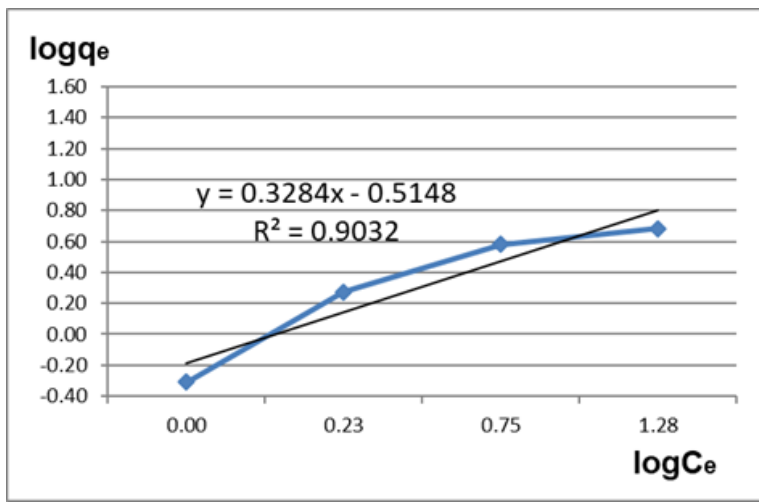

Figure 10. The Freundlich isotherm model for NOR adsorption on $\mathrm{CL}$

electrostatic interaction between the adsorbent surface and adsorbate.

The adsorption process under dynamic conditions was investigated using the laboratory dynamic type equipment with packed fixed-bed adsorption column. The behaviours of breakthrough curves for MOX $\mathrm{HCl}$ and NOR adsorption on CL and H-CL at different flow rates of $1.5,2.5,5.0 \mathrm{~mL} / \mathrm{min}$ of the FQ antibiotic solution with two different inlet concentration - 0.2 $\mathrm{mg} / \mathrm{mL}$ and $1.0 \mathrm{mg} / \mathrm{mL}$ were observed. According to the breakthrough curves (Figure 11,12) in case of CL, it can be observed that the breakthrough times $\mathrm{C} / \mathrm{C}_{0}=0.05$ at the values of volumetric flow rates of $1.5 \mathrm{~mL} / \mathrm{min}$ and $5.0 \mathrm{~mL} / \mathrm{min}$ are reported as 25 and 20 min for $\mathrm{MOX} \mathrm{HCl}, 20$ and $15 \mathrm{~min}$ for NOR, respectively. This can be related to low molecular interaction between adsorbate and adsorbent at a 
higher flow rate, which accelerates breakthrough and saturation. The early breakthrough of NOR compared to $\mathrm{MOX} \mathrm{HCl}$ is caused by little higher adsorption of NOR. For both adsorbates, the breakthrough curve at high volumetric flow rate is shifted toward the origin and become steeper and rapidly reached saturation. At time of $100 \mathrm{~min}$, the value of effluent to influent concentration ratio $\mathrm{C} / \mathrm{C}_{0}$ for $\mathrm{MOX} \mathrm{HCl}$ at the flow rate of $1.5 \mathrm{~mL} / \mathrm{min}$ is at least 1.5 times lower than its value at $5.0 \mathrm{~mL} / \mathrm{min}$. As the flow rate drops, the adsorbate has sufficient time to diffuse through pores and produces a higher adsorption capacity. Besides, the high flow rate reduces the thickness of liquid film around adsorbent particles leading to low mass transfer resistance and a high rate of mass transfer. So, according to the breakthrough curves (Figure 13,14) at the various flow rates in case of H-CL, it can be observed that at the same volumetric flow rate of 1.5 $\mathrm{mL} / \mathrm{min}$ and at the same breakthrough time of 100 min, the value of ratios $C / \mathrm{C}_{0}$ are approximately 0.95 and 0.60 for CL and H-CL, respectively. This can be related to low molecular interaction between

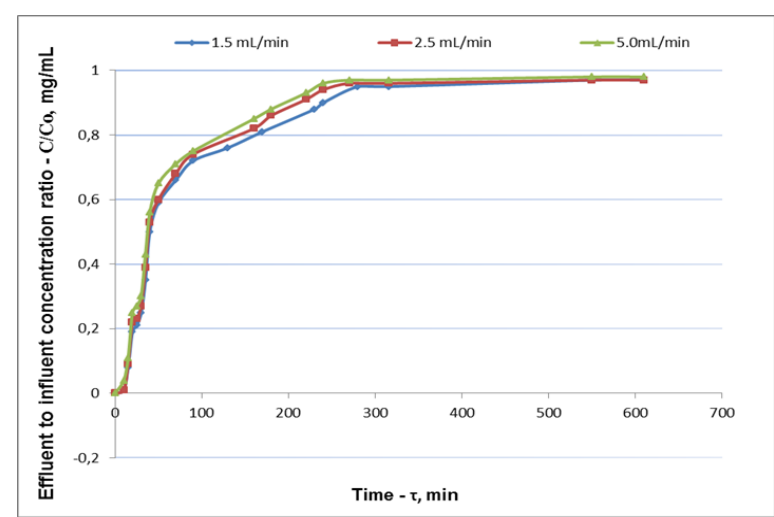

Figure 11. The breakthrough curve of MOX HCL adsorption on $\mathrm{CL}$ at various flow rates

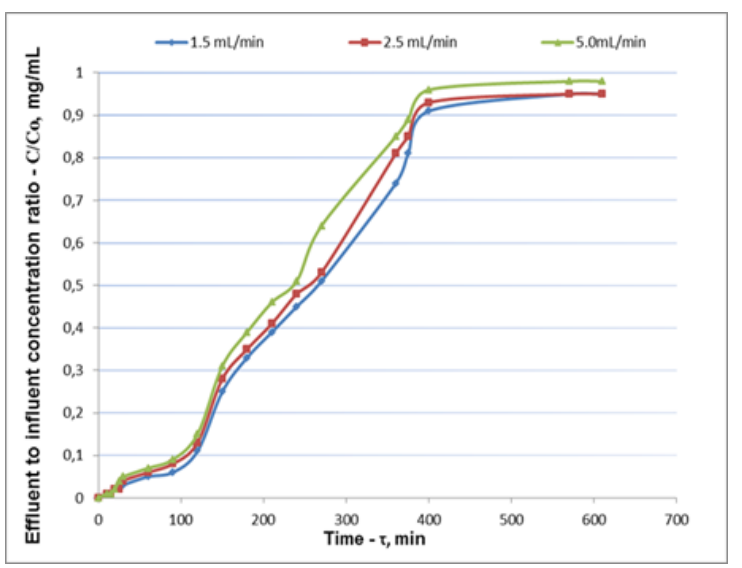

Figure 13. The breakthrough curve of $\mathrm{MOX} \mathrm{HCl}$ adsorption on $\mathrm{H}-\mathrm{CL}$ at various flow rates

The curve presented in Figure 15 shows the influence of FQ antibiotic inlet concentration $(0.2 \mathrm{mg} / \mathrm{mL}$ and $1.0 \mathrm{mg} / \mathrm{mL}$ ) on the behaviour of the breakthrough curve at a constant adsorbate solution temperature of $20^{\circ} \mathrm{C}$ and at the same flow rate of $1.5 \mathrm{~mL} / \mathrm{min}$. The adsorbates and CL which accelerates breakthrough and saturation. The early breakthrough of adsorbate compared to H-CL is due to relatively low adsorption. The mechanism of interaction between adsorbate and adsorbent can be explained that CL has a frame, open and stable three-dimensional structure with a negative charge, and FQ antibiotics have positively charged functional groups. Therefore, natural clinoptilolite would be able to retain antibiotics via cation exchange mechanism. However, it is hypothesized that antibiotics are uptake by zeolite in connection with $\pi-\pi$ electron-donor-acceptor interaction on moxifloxacin $\mathrm{HCl}$ and norfloxacin as the predominant mechanism of adsorption. The $\pi-\pi$ electron-donoracceptor interaction between the benzene ring and carboxyl of FQs and hydroxyl groups on the zeolite adsorbent surface may be the major factor. Increasing adsorption capacity in case of H-CL is connected with the effect of the modification, including pore sizes. Its porous structure change provides a large surface area for adsorption

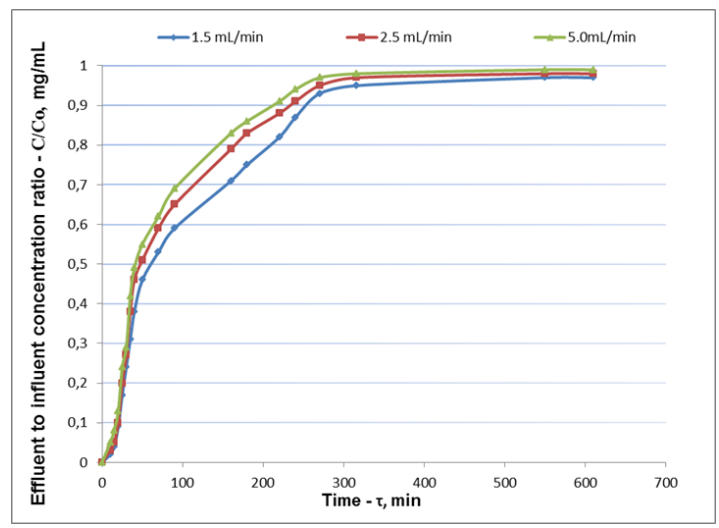

Figure 12. The breakthrough curve of NOR adsorption on $\mathrm{CL}$ at various flow rates

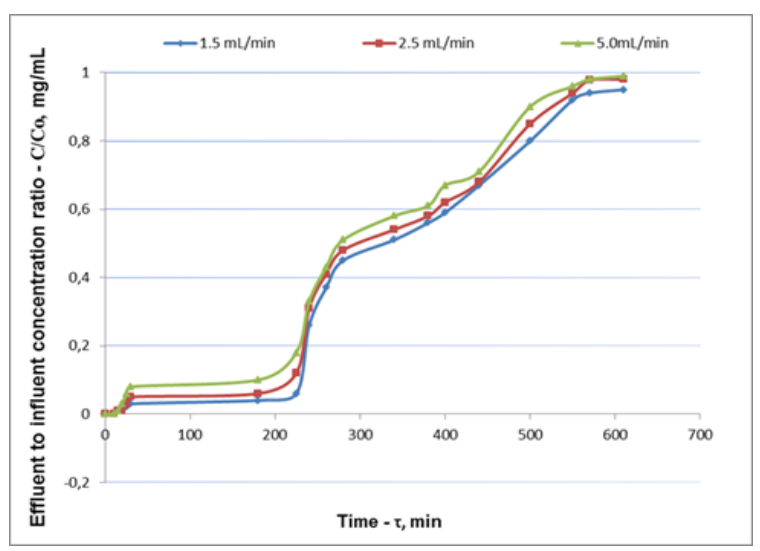

Figure 14. The breakthrough curve of NOR adsorption on $\mathrm{H}-\mathrm{CL}$ at various flow rates

results show that the breakthrough curve is shifted towards the origin at higher inlet concentration. This behaviour may be related to the enhancement of driving force for mass transfer across the liquid film along with the acceleration of adsorption rate, which 
leads to an early saturation of the fixed-bed column. More precisely, the inlet $\mathrm{MOX} \mathrm{HCl}$ concentration of 0.2 and $1.0 \mathrm{mg} / \mathrm{mL}$, the values of $\mathrm{C} / \mathrm{C}_{0}$ at a contact time of $150 \mathrm{~min}$ are reported as 0.04 , and 0.13 , respectively. These results for inlet concentration effect on the breakthrough curve show that the fixed bed adsorption conditions affect the value of ratio $\mathrm{C} / \mathrm{C}_{0}$ for both $\mathrm{FQ}$ antibiotics according to the order: the inlet concentration $>$ the volumetric flow rate.

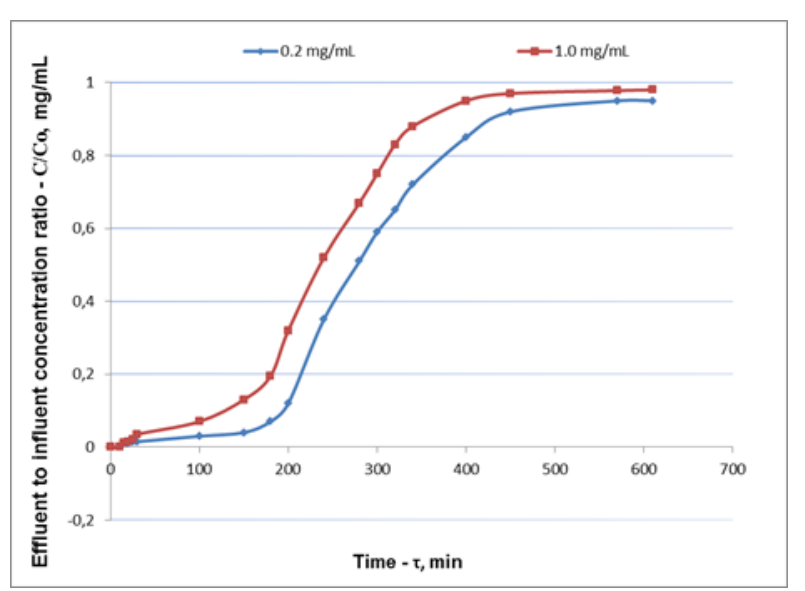

Figure 15. The breakthrough curve of MOX on CL at various inlet concentration of adsorbate solution

The value of $\mathrm{pH}$ of the antibiotic solution can affect and change the adsorbent surface charge and correspondingly, the adsorption efficiency. The effect of $\mathrm{pH}$ value was investigated in acidic $(\mathrm{pH} 4)$ and neutral ( $\mathrm{pH} 7)$ conditions. On the base of the results

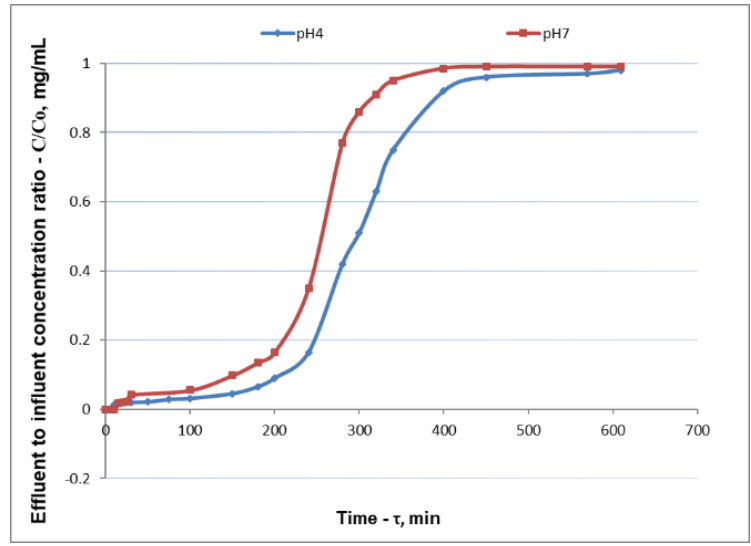

Figure 16. The breakthrough curve of MOX CL at various $\mathrm{pH}$ values

As shown in Figures 16 and 17 along with the $\mathrm{pH}$ dependent speciation, moxifloxacin molecule can be more positively charged (cationic). Cationic moxifloxacin is the dominant species at the value of $\mathrm{pH}$ below 7. At $\mathrm{pH} 4$ the cationic MOX molecule has carboxylic acid, which may be the dominant mechanism of this adsorption. In acidic solution, carboxyl and amino groups are more protonated. At the value of $\mathrm{pH} \mathrm{7,} \mathrm{zeolite} \mathrm{adsorbent} \mathrm{surface} \mathrm{can} \mathrm{be}$ negatively charged and hence, is the possibility of stronger electrostatic interaction. The carboxyl group MOX molecule become anionic with increasing the value of $\mathrm{pH}$, which cannot combine with the adsorbent surface. The results confirm that the effect of electric charge is a small impact role in the process because MOX molecules and adsorbent surface are obtained, the adsorption efficiency profile for both antibiotics is similar for both zeolites; also the breakthrough curve at $\mathrm{pH} 4.0$ is similar to the experimental data achieved at $\mathrm{pH} 7$

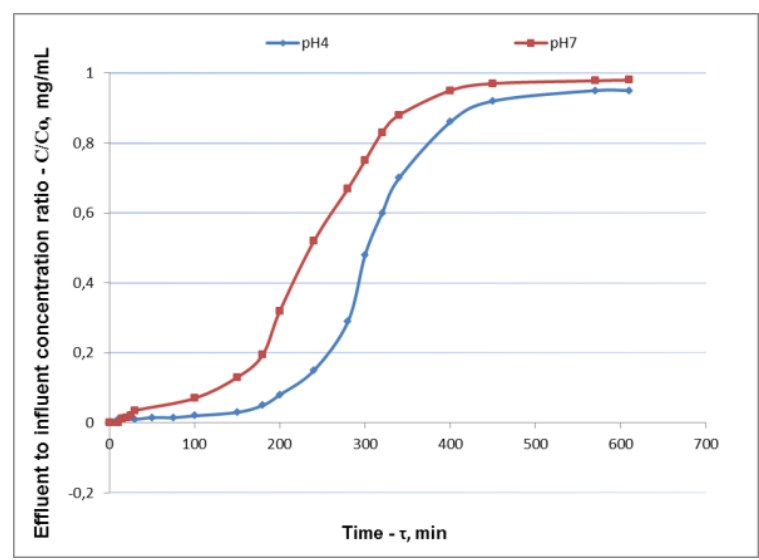

Figure 17. The breakthrough curve of MOX H-CL at various $\mathrm{pH}$

the same charges at $\mathrm{pH} 4$ and $\mathrm{pH} 7$. The $\pi-\pi$ electrondonor-acceptor interaction of the adsorption was the most effective at $\mathrm{pH}$ 4. The same results were obtained in case of NOR.

Additionally, according to the breakthrough curves given in Figure 16,17, at time of $200 \mathrm{~min}$, the value of effluent to influent concentration ratio $\mathrm{C} / \mathrm{C}_{0}$ for $\mathrm{MOX}$ $\mathrm{HCl}$ at the value of $\mathrm{pH} 4$ is at least 2-4 times lower than its value at the value of $\mathrm{pH} 7$ on both zeolites. Therefore, the observation of the removal efficiency with increasing the value of $\mathrm{pH}$ can be explained by lower electrostatic interaction between FQ antibiotic and zeolite adsorbent. The interaction between the acid sites of the zeolite and the functional groups of the adsorbate is one crucial parameter that affects the 
equilibrium adsorption mechanism. Zeolite acidity increases in strength as the molar ratio of $\mathrm{SiO}_{2} / \mathrm{A}_{2} \mathrm{O}_{3}$ decreases due to the increase in $\left(\mathrm{AlO}^{-}{ }_{4 / 2}\right)$ sites, which strengthens the electrostatic field in the zeolite and increases the number of acid sites. The terminal Si$\mathrm{OH}$ on the zeolite surface can be protonated under acid conditions resulting in the positive surface charge of zeolites ${ }^{51}$. At $\mathrm{pH}$ higher than the $\mathrm{pKa}$ value of FQ antibiotics, the dominant adsorbed species is the negatively charged form, so, the adsorption mechanism involves repulsive electrostatic interaction, which explains the decreased adsorption efficiency. Hence, the results show that adsorption of FQ antibiotics on CL and H-CL has no significant changes under $\mathrm{pH}$ 4-7 range.

The adsorption capacity (or loading) is the amount of adsorbate taken up by the adsorbent per unit mass of the adsorbent. There are two static and dynamic adsorption capacities. The static adsorption capacity is greater than the dynamic adsorption capacity. Generally, the dynamic equilibrium loading is $30 \%$ $70 \%$ of the static capacity. The static adsorption capacity is the maximum theoretical capacity of the adsorbent and can be used for comparison of different adsorbent while the dynamic adsorption capacity is used to calculate the required filling amount of adsorbents until the saturation state occurred. The dynamic adsorption capacities of both studied adsorbents - natural clinoptilolite and clinoptilolite $\mathrm{H}$ modified form were calculated by the equation (5) based on the adsorption experiment performed under dynamic conditions. The results obtained by calculations are listed in Tables 2,3. The data show that the decrease of the dynamic adsorption capacities of both FQ antibiotics was caused by increasing the flow rate and the inlet concentration of each adsorbate solution. Thus, the high adsorption capacities were observed for norfloxacin compared to second FQ antibiotic - moxifloxacin $\mathrm{HCl}$, which can be explained with higher water solubility and lower molecular weight of norfloxacin relative to moxifloxacin $\mathrm{HCl}$. This fact may be associated with enhancement of driving force for mass transfer across the liquid film along with the acceleration of adsorption rate, which leads to an early saturation of the fixed-bed adsorbent column in case of dynamic adsorption conditions. Clinoptilolite acid-modified $\mathrm{H}$ form is characterized by higher adsorption dynamic capacity caused by increasing the $\mathrm{Si} / \mathrm{Al}$ ratio in the zeolite framework and pore opening in comparison with natural clinoptilolite. The fact was confirmed by XRD analysis results.

Table 2. The dynamic adsorption capacities, mg/g for CL-MOX/NOR and H-CL-MOX/NOR systems with different flow rates of FQ antibiotics solutions with different inlet concentrations at the value of $\mathrm{pH} 7$.

\begin{tabular}{|c|c|c|c|c|c|c|c|c|c|}
\hline \multirow{2}{*}{ Adsorbent } & \multicolumn{4}{|c|}{ Moxifloxacin HCl } & \multicolumn{4}{c|}{ Norfloxacin } \\
\cline { 2 - 9 } & $\mathbf{1 . 5} \mathbf{~ m L / m i n}$ & $\mathbf{5 . 0} \mathbf{~ m L / m i n}$ & $\mathbf{1 . 5} \mathbf{~ m L / m i n}$ & $\mathbf{5 . 0} \mathbf{~ m L / m i n}$ \\
\cline { 2 - 9 } & $\mathbf{0 . 2}$ & $\mathbf{1 . 0}$ & $\mathbf{0 . 2}$ & $\mathbf{1 . 0}$ & $\mathbf{0 . 2}$ & $\mathbf{1 . 0}$ & $\mathbf{0 . 2}$ & $\mathbf{1 . 0}$ \\
& $\mathbf{m g} / \mathbf{m L}$ & $\mathbf{m g} / \mathbf{m L}$ & $\mathbf{m g} / \mathbf{m L}$ & $\mathbf{m g} / \mathbf{m L}$ & $\mathbf{m g} / \mathbf{m L}$ & $\mathbf{m g} / \mathbf{m L}$ & $\mathbf{m g} / \mathbf{m L}$ & $\mathbf{m g} / \mathbf{m L}$ \\
\hline Natural Clinoptilolite & 0.48 & 0.35 & 0.27 & 0.25 & 0.76 & 0.55 & 0.34 & 0.32 \\
\hline Clinoptilolite H-Form & 1.20 & 0.46 & 0.37 & 0.35 & 2.10 & 0.69 & 0.61 & 0.44 \\
\hline
\end{tabular}

Table 3. The static adsorption capacities, mg/g for CL-MOX/NOR and H-CL-MOX/NOR systems at different inlet concentrations of FQ antibiotics solutions and the value of $\mathrm{pH} 7$.

\begin{tabular}{|c|c|c|c|c|}
\hline \multirow{2}{*}{ Adsorbent } & \multicolumn{2}{|c|}{ Moxifloxacin HCl } & \multicolumn{2}{c|}{ Norfloxacin } \\
\cline { 2 - 5 } & $\mathbf{0 . 2} \mathbf{~ m g / m L}$ & $\mathbf{1 . 0} \mathbf{~ m g / m L}$ & $\mathbf{0 . 2} \mathbf{~ m g / m L}$ & $\mathbf{1 . 0} \mathbf{~ m g / m L}$ \\
\hline Natural Clinoptilolite & 1.72 & 1.44 & 2.22 & 1.73 \\
\hline Clinoptilolite H-Form & 2.71 & 2.54 & 4.14 & 3.31 \\
\hline
\end{tabular}

The adsorption of both fluoroquinolone antibiotics moxifloxacin $\mathrm{HCl}$ and norfloxacin on natural clinoptilolite and clinoptilolite acid-modified H-form is practically the same with little differences and has higher breakthrough rate relative to other antibiotic pollutants.

\section{Conclusion}

The selected natural zeolite - clinoptilolite and its acid-modified $\mathrm{H}$-form with hydrophilic pores have a higher affinity for adsorbing FQ antibiotics in aqueous solution. The experimental data show that the high value of the volumetric flow rate, the inlet concentration of the antibiotic solution and the $\mathrm{pH}$ value accelerates breakthrough of adsorbates and correspondingly reduces the adsorption capacities. The capacities of moxifloxacin $\mathrm{HCl}$ and norfloxacin adsorption are strongly dependent on the volumetric flow rate and the inlet concentration of the fluoroquinolone antibiotic solution. The value of $\mathrm{pH}$ does not have a significant influence on the adsorption process. The removal efficiency increased with a decrease in the concentration of adsorbate solution. The amount of FQ antibiotic adsorbed per unit mass of zeolite as a function of the contact time of each adsorbate with adsorbent, the structure, the molecular weight and the concentration of FQ antibiotic in solution. The highest static adsorption capacities were observed at low initial concentration $-0.2 \mathrm{mg} / \mathrm{mL}$ of antibiotic solution for both adsorbents; the highest dynamic adsorption capacities - at low flow rate 
$1.5 \mathrm{mg} / \mathrm{mL}$ and low inlet concentration $-0.2 \mathrm{mg} / \mathrm{mL}$ of antibiotic solution for both adsorbents. The static adsorption capacity was up to $2.71 \mathrm{mg} / \mathrm{g}$ for moxifloxacin hydrochloride; $4.14 \mathrm{mg} / \mathrm{g}$ for norfloxacin and the dynamic adsorption capacity was up to $1.20 \mathrm{mg} / \mathrm{g}$ for moxifloxacin hydrochloride; 2.10 $\mathrm{mg} / \mathrm{g}$ for norfloxacin at a neutral $\mathrm{pH}$ value and constant temperature of $20^{\circ} \mathrm{C}$.

Additionally, this research provides useful information for the design of fixed bed adsorption column for removal studies of other antibiotics of different classes or organic contaminants. Further investigations are required to assess of detailed adsorption process using natural zeolites aiming a better design of zeolite in the real scenario. Some considerations should be addressed in the future studies, including the dominant interactions between contaminant-natural zeolite, as well as to improve the understanding of adsorption mechanism for other antibiotics of fluoroquinolone family and other classes of antibiotics.

Hence, this research indicates that natural zeolite clinoptilolite from Khandaki, Georgia is an efficient, eco-friendly, alternative and competitive adsorbent in terms of cheapness, shape selectivity and adsorption efficacy for the removal of the frequently used fluoroquinolone antibiotics from wastewaters and implemented in an industrial setting for separation and purification processes.

\section{Acknowledgment}

The research was financially supported by the Shota Rustaveli National Science Foundation within the framework of project \#217138.

\section{References}

1- A. Fleming, The discovery of penicillin, Br. Med. Bull, 1944, 2, 4-5.

2- K. Kummerer, Antibiotics in the aquatic environment - A review - Part I, Chemosphere, 2009, 75(4), 417-434.

3- R. Wise, Antimicrobial resistance: priorities for action, J. of Antimicrob. Chemother., 2002, 49(4), 585-586.

4- S.T. Glassmeyer, E.K. Hinchey, S.E. Boehme, C.G. Daughton, I.S. Ruhoy, O. Conerly, R.L. Daniels, L. Lauer, M. McCarthy, T.G. Nettesheim, K. Sykes, and V.G. Thompson, Disposal practices for unwanted residential medications in the United States, Environ. Int., 2009, 35(3), 566-572.

5- F.Yu, Y. Li, S. Han, J. Ma, Adsorptive removal of antibiotics from aqueous solution using carbon materials, Chemosphere, 2016, 153, 365-385.

6- G. Moussavi, A. Alahabadi, K. Yaghmaeian, M. Eskandari, Preparation, characterization and adsorption potential of the $\mathrm{NH}_{4} \mathrm{Cl}$-induced activated carbon for the removal of amoxicillin antibiotic from water, Chem. Eng. J., 2013, 217, 119-128.

7- X. Chang, M.T. Meyer, X. Liu, Q. Zhao, H. Chen, J.-a. Chen, Z. Qiu, L. Yang, J. Cao, W. Shu, Determination of antibiotics in sewage from hospitals, nursery and slaughterhouse, wastewater treatment plant and source water in Chongqing region of Three Gorge Reservoir in China, Environ.l Pollut., 2010, 158(5), 14441450.

8- K.D. Brown, J. Kulis, B. Thomson, T.H. Chapman, D.B. Mawhinney, Occurrence of antibiotics in the hospital, residential, and dairy effluent, municipal wastewater, and the Rio Grande in New Mexico, Sci. Total Environ., 2006, 366(2-3), 772-783.

9- A.J. Watkinson, E.J. Murby, D.W. Kolpin, S.D. Costanzo, the occurrence of antibiotics in an urban watershed: From wastewater to drinking water. Sci. Total Environ., 2009, 407(8), 27112723.

10-M. Hernando, M. Mezcua, A. Fernandezalba, D. Barcelo, Environmental risk assessment of pharmaceutical residues in wastewater effluents, surface waters and sediments, Talanta, 2006, 69(2), 334-342.

11-S.D., Costanzo, J. Murby, J. Bates, Ecosystem response to antibiotics entering the aquatic environment, Mar. Pollut. Bull., 2005, 51(1-4), 218-223.

12-J.J. Holstein, C.B. Hübschle, B. Dittrich, Electrostatic properties of ninefluoroquinolone antibiotics derived directly from their crystal structure refinements, Cryst. Eng. Comm., 2012, 14, 2520-2531.

13-L.E. Bryan, J. Bedard, S. Wong, S. Chamberland, Quinolone antimicrobial agents: Mechanism of action and resistance development, Clin. Invest. Med., 1989, 12, 14-19.

14-E.M. Golet, A.C. Alder, W. Giger, Environmental exposure and risk assessment of fluoroquinolone antibacterial agents in wastewater and river water of the Glatt Valley Watershed, Switzerland, Environ. Sci. Technol., 2002, 36, 3645-3651.

15-B. Prutthiwanasan, C. Phechkrajang, L. Suntornsuk, Fluorescent labeling of ciprofloxacin and norfloxacin and its application for residues analysis in surface water, Talanta, 2016, 159, 7479.

16-Ai Jia, Yi Wan, Yang Xiao, Jianying Hu, Occurrence and fate of quinolone and fluoroquinolone antibiotics in a municipal sewage treatment plant, Water Res., 2012, 46(2), 387-394.

17-T.A. Choi, Side Effects of Drugs Annual; Chapter 26 - Miscellaneous antibacterial drugs; Volume 35; Ed. by J.K. Aronson; Elsevier: Amsterdam, 2014, pp. 463-481.

18-M.T. Darweesh, M.J. Ahmed, Adsorption of ciprofloxacin and norfloxacin from aqueous solution onto granular activated carbon in fixed- 
bed column, Ecotoxicol. Environ. Safety, 2017, 138 139-145.

19-S. Suzuki, P.T. Phuong Hoa, Distribution of quinolones, sulfonamides, tetracyclines in an aquatic environment and antibiotic resistance in Indochina, Front. Microbio., 2012, 3(67).

20-I.T. Carvalho, L. Santos, Antibiotics in the aquatic environments: A review of the European scenario, Environ. Int., 2016, 94, 736-757.

21-US Pharmacopeia National Formulary USP 41NF-36, Moxifloxacin, The United States Pharmacopeial Convention; United Book Press, Inc: Baltimore, 2018, pp. 8361-8363.

22-US Pharmacopeia National Formulary USP 41NF-36. Norfloxacin, The United States Pharmacopeial Convention; United Book Press, Inc: Baltimore, 2018, pp. 2976-2977.

23-N. Le-Minh, S.J. Khan, J.E. Drewes, R.M. Stuetz, Fate of antibiotics during municipal water recycling treatment processes, Water Res., 2010, 44(15), 4295-4323.

24-J. Torres-Pérez, C. Gérente, Y. Andrès, Sustainable activated carbons from agricultural residues dedicated to antibiotic removal by adsorption, Chin. J. Chem. Eng., 2012, 20, 524529.

25-L. Zhu, B. Santiago-Schübel, H. Xiao, H. Hollert, S. Kueppers, S., Electrochemical oxidation of fluoroquinolone antibiotics: mechanism, residual antibacterial activity and toxicity change, Water Res., 2016, 102, 52-62.

26-M. C`vančarová, M. Moeder, A. Filipová, T. Cajthaml, Biotransformation of fluoroquinolone antibiotics by ligninolytic fungi-metabolites, enzymes and residual antibacterial activity, Chemosphere, 2015, 136, 311-320.

27-F. Maraschi, M. Sturini, A. Speltini, L. Pretali, A. Profumo, A. Pastorello, $\mathrm{TiO}_{2}$-modified zeolites for fluoroquinolones removal from wastewaters and reuse after solar light regeneration, $J$. Environ. Chem. Eng., 2014, 2, 2170-2176.

28-M. Feng, X. Wang, J. Chen, R. Qu, Y. Sui, L. Cizmas, Z. Wang, V.K. Sharma, Degradation of fluoroquinolone antibiotics by ferrate (VI): effects of water constituents and oxidized products. Water Res. 2016, 103, 48-57.

29-B. Ebrahimpour, Y. Yamini, M. Moradi, Application of ionic surfactant as a carrier and emulsifier agent for the microextraction of Fluoroquinolones, J. Pharm. Biomed. Anal., 2012, 66, 264-270.

30-H. Guo, N. Gao, Y. Yang, Y. Zhang, Kinetics and transformation pathways on oxidation of Fluoroquinolones with thermally activated persulfate, Chem. Eng. J., 2016, 292, 82-91.

31-V.R.A. Ferreira, C.L. Amorim, S.M. Cravo, M.E. Tiritan, Fluoroquinolones biosorption onto microbial biomass: activated sludge and aerobic granular sludge, Int. Biodeterior. Biodegrad., 2016, 110, 53-60.

32-F. Tan, D. Sun, J. Gao, Q. Zhao, X. Wang, F. Teng, X. Quan, J. Chen, Preparation of molecularly imprinted polymer nanoparticles for selective removal of fluoroquinolone antibiotics in aqueous solution, J. Hazard. Mater., 2013, 244-245, 750-757.

33-I. Braschi, G. Gatti, G. Paul, C.E. Gessa, M. Cossi, L. Marchese, Sulfonamide antibiotics embedded in high silica zeolite Y: a combined experimental and theoretical study of host-guest and guest-guest interactions, Langmuir, 2010, 26(12), 9524-9532.

34-J. Cao, C. Lei, B. Yang, Z. Li, L. Lei, Y. Hou, X. Feng, Zeolitic imidazolate framework derived core-shell-structured $\mathrm{CoS}_{2} / \mathrm{CoS}_{2}-\mathrm{N}-\mathrm{C}$ supported on electrochemically exfoliated graphene foil for efficient oxygen evolution, Batt. Supercaps, 2018, 1, 1-8.

35-A. Zukal, M. Shamzhy, M. Kubů, J. Čejka, The effect of pore size dimensions in isoreticular zeolites on carbon dioxide adsorption heats, $J$. $\mathrm{CO}_{2}$ Util., 2018, 24, 157-163.

36-Z. Chen, W. Maa, G. Lub, F. Menga, S. Duana, Z. Zhanga, L. Weic, Y. Pana, Adsorption of levofloxacin onto mechanochemistry treated zeolite: Modeling and site energy distribution analysis, Sep. Purif. Technol., 2019, 222, 30-34.

37-S.S. Salih, T.K. Ghosh, Preparation and characterization of chitosan-coated diatomaceous earth for hexavalent chromium removal, Environ. Processes, 2018, 5, 23-39.

38-S.S. Salih, T.K. Ghosh, Preparation and characterization of bioadsorbent beads for chromium and zinc ions adsorption, Cogent Environ. Sci., 2017, 3, 1401577.

39-S.S. Salih, T.K. Ghosh, Adsorption of Zn(II) ions by chitosan coated diatomaceous earth, Int. J. Biol. Macromol., 2018, 106, 602-610.

40-Z. Liang, Z. Zhao, T. Sun, W. Shi, F. Cui, Adsorption of quinolone antibiotics in spherical mesoporous silica: effects of the retained template and its alkyl chain length, J. Hazard. Mater., 2016, 305, 8-14.

41-H. Liu, W. Ning, P. Cheng, J. Zhang, Y. Wang, C. Zhang, Evaluation of animal hairs-based activated carbon for sorption of norfloxacin and acetaminophen by comparing with cattail fiberbased activated carbon, J. Anal. Appl. Pyrolysis, 2013, 101, 156-165.

42-Y. Patiño, E. Díaz, S. Ordóñez, Pre-concentration of nalidixic acid through adsorption-desorption cycles: adsorbent selection and modeling, Chem. Eng. J., 2016, 283,486-494.

43-A. Martucci, L. Pasti, N. Marchetti, A. Cavazzini, F. Dondi, A. Albertia, Adsorption of pharmaceuticals from aqueous solutions on synthetic zeolites, Micropor. Mesopor. Mater., 2012, 148(1), 174-183.

44-D. Ašperger, I. Varga, S. Babić, L. Ćurković, Adsorption fenrofloxacine on natural zeolite clinoptilolite, Holistic Approach Environ., 2014, 4(1), 3-15. 
45-G.V. Tsitsishvili, T.G. Andronikashvili, G.R. Kirov, and L.D. Filizova, Natural Zeolites; Ellis Horwood Limited: Chichester, 1991, p. 297.

46-Y. Garci-Basabe, I. Rodriguez-Iznaga, L.C. De Menorval, P. Llewellyn, G. Maurin, D.W. Lewis, R. Binions, M. Autie, A.R. Ruiz-Salvador, Stepwise dealumination of natural clinoptilolite: Structural and physicochemical characterization, Micropor. Mesopor. Mater., 2010, 135, 187-196.

47-Atlas of Zeolite Framework Types; ed by Ch. Baerlocher, L.B. McCucker, and D.H. Olson, Elsevier: Amsterdam, 2007, pp. 156-157.

48-T.G. Andronikashvili, T.N. Kordzakhia, L.G. Eprikashvili, Zeolitese the Unique Desiccating Agents of Organic Liquids; Lap Lambert Academic Publishing, 2015, p.100.

49-L.Eprikashvili, M.Zautashvili, T.Kordzakhia, N.Pirtskhalava, M.Dzagania, I. Rubashvili, V. Tsitsishvili, Intensification of bioproductivity of agricultural cultures by adding natural zeolites and brown coals into soils, Ann. Agr. Sci., 2016, 14, 67-71.

50-I. Rubashvili, M. Zautashvili, T. Kordzakhia, L. Eprikashvili, Development and validation of quantitative determination HPLC methods of the fluoroquinolone antibiotics - moxifloxacin hydrochloride and norfloxacin in support of adsorption study on natural zeolites, Periódico Tchê Química, 2019, 16, 10-20 (Article in press).

51-E. Milchert, W. Goc, R. Pelech, Adsorption of $\mathrm{CCl}_{4}$ from aqueous solution on activated carbons, Adsorpt. Sci. Technolog., 2000, 18, 823-837.

52-D.N. Ribeiro de Sousa, S. Insa, A. A. Mozeto, M. Petrovic, T.F. Chaves, P.S. Fadini, Equilibrium and kinetic studies of the adsorption of antibiotics from aqueous solutions onto powdered zeolites, Chemosphere, 2018, 205, 137-146.

53-M.M. Mohammed Ali, M.J. Ahmed, B.H. Hameed, NaY zeolite from wheat (Triticum aestivum L.) straw ash used for the adsorption of tetracycline, J. Clean. Prod., 2018, 172, 602-608. 